\title{
BURNOUT DAN KAITANNYA DENGAN TIPE KEPRIBADIAN INTROVERT
}

\author{
BURNOUT AND ITS RELEVANCE WITH INTROVERT PERSONALITY TYPE
}

\author{
Oleh : \\ Yuniar Siwi Dwi Atia ${ }^{1}$ \\ Christiana Hari Soetjiningsih ${ }^{2}$
}

\begin{abstract}
Submitted:

02 November 2019

Revision:

30 Desember 2019

Accepted:

31 Desember 2019

This purpose of this study is to examine whether introvert personality types can lead to burnout at nurses who work in RSUD Karanganyar. The study population is all nurses in RSUD Karanganyar totaling 269 nurses. The subjects of this study involved 84 nurses with the characteristics of the subject being nurses who had worked for at least 1 year. The scale used in this study is the introvert personality scale composed by Eysenck and the burnout scale composed by Maslach. Data analysis technique used is Spearman's Rho. The results of data analysis show that there is a strong and significant positive relationship between introvert personality types and burnout at nurses who work in RSUD Karanganyar, which is the stronger the introvert personality types owned by nurses, the higher the level of burnout experienced, so the hypothesis of this study is accepted. This indicates that the introvert personality types are determining the chances of burnout appearing at nurses who work in RSUD Karanganyar.
\end{abstract}

Keywords: Burnout; Introvert Personality Type; Nurse; RSUD.

\begin{abstract}
ABSTRAK
Penelitian ini bertujuan untuk menguji apakah tipe kepribadian introvert dapat mengakibatkan burnout pada perawat yang bekerja di RSUD Karanganyar. Populasi penelitian adalah seluruh perawat di RSUD Karanganyar yang berjumlah 269 perawat. Subjek penelitian ini melibatkan perawat sebanyak 84 orang dengan karakteristik subjek adalah perawat yang minimal sudah bekerja selama 1 tahun di RSUD Karanganyar. Skala yang digunakan dalam penelitian ini yaitu skala kepribadian introvert yang disusun oleh Eysenck dan skala burnout yang disusun oleh Maslach. Teknik analisis data yang digunakan adalah Spearman's Rho. Hasil analisis data menunjukkan bahwa terdapat hubungan positif yang kuat dan signifikan antara variabel tipe kepribadian introvert dengan burnout pada perawat RSUD Karanganyar, dimana semakin kuat tipe kepribadian introvert yang dimiliki oleh perawat, maka semakin tinggi tingkat burnout yang dialami, sehingga hipotesis dalam penelitian ini diterima. Hal tersebut mengindikasikan bahwa tipe kepribadian introvert menentukan peluang munculnya burnout pada perawat di RSUD Karanganyar.
\end{abstract}

Kata kunci: Burnout, Perawat, RSUD, Tipe Kepribadian Introvert

\footnotetext{
${ }^{1}$ Yuniar Siwi Dwi Atia, Fakultas Psikologi Universitas Kristen Satya Wacana Salatiga, Email: tia20986@gmail.com

${ }^{2}$ Christiana Hari Soetjiningsih, Dosen Fakultas Psikologi Universitas Kristen Satya Wacana Salatiga,

Email: soetji_25@yahoo.co.id
} 


\section{PENDAHULUAN}

Perawat adalah profesi kesehatan yang jumlah dan kebutuhannya paling banyak diantara tenaga kesehatan lainnya. Berdasarkan data dari Badan Pengembangan dan Pemberdayaan Sumber Daya Manusia Kesehatan (BPPSDMK), persentase jumlah perawat adalah yang terbesar di antara tenaga kesehatan lainnya, yaitu 29,66\% dari seluruh rekapitulasi tenaga kesehatan di Indonesia per Desember 2016 (dalam Infodatin Kemenkes RI, 2017). Anjaswarni (dalam Juniar, Iftadi, \& Astuti, 2017) juga menjelaskan bahwa tim keperawatan termasuk dalam sumber daya manusia rumah sakit yang memiliki peran penting dalam memberikan pelayanan kesehatan kepada pasien, hal ini dikarenakan perawat secara terus menerus melayani pasien selama 24 jam di rumah sakit. Oleh karena pentingnya peran seorang perawat, maka dari itu dibutuhkan perawat yang menguasai keahlian dalam profesi keperawatan dan berada dalam kondisi yang prima untuk melayani pasien di rumah sakit. Jika mutu pelayanan dan kinerja perawat baik, maka akan berdampak baik pula pada mutu pelayanan dan kinerja rumah sakit.

Demikian pula halnya dengan perawat yang bekerja di RSUD Karanganyar. Di dalam melaksanakan tugas dan tanggung jawab sebagai pemberi layanan kesehatan, para perawat memiliki peran yang sangat penting dalam memberikan asuhan keperawatan secara profesional kepada seluruh pasien di RSUD Karanganyar. Berdasarkan hasil wawancara yang dilakukan 15 Juli 2019 dengan perawat yang bekerja di RSUD Karanganyar, diperoleh informasi bahwa adanya shift kerja merupakan salah satu penyebab timbulnya kelelahan pada perawat. Sebagian besar perawat menyatakan bahwa shift kerja yang paling berat adalah shift kerja pada malam hari. Hal ini disebabkan oleh panjangnya durasi shift malam yang berlangsung selama 12 jam, mulai dari jam 8 malam hingga jam 8 pagi ketika pergantian shift. Hal ini didukung oleh pernyataan Depkes RI yang menyatakan bahwa didapatkan sekitar 30-40\% masyarakat pekerja pemberi jasa layanan kesehatan yang bersifat teknis dan beroperasi selama 8-24 jam sehari mengalami kelelahan. Hal ini disebabkan oleh adanya pola kerja bergilir/shift kerja (dalam Juniar, Iftadi, \& Astuti, 2017).

Selain itu, berdasarkan hasil wawancara yang dilakukan oleh penulis dengan perawat yang bekerja di RSUD Karanganyar pada tanggal 17 Juli 2019 didapatkan informasi bahwa adanya beban kerja yang berat dan stresor yang tinggi juga menyebabkan beberapa masalah kesehatan pada sebagian besar perawat, seperti kelelahan, pusing, vertigo dan stres. Pernyataan tersebut sesuai dengan hasil survei yang dilakukan oleh Persatuan Perawat Nasional Indonesia (PPNI) pada tahun 2006 yang menunjukkan bahwa sekitar 50,9\% perawat mengalami stress, sering pusing, dan kelelahan akibat pekerjaannya (Rachmawati dalam Mariyanti, 2011).

Kemudian di dalam wawancara tersebut penulis juga mendapatkan sebagian besar perawat menyatakan bahwa banyaknya jumlah pasien yang membutuhkan pengawasan dengan tingkat kedaruratan yang berbeda-beda, dari non emergensi hingga kritis, banyaknya pasien kritis yang dirawat di bangsal, dan komplain dari pasien yang mengeluh mengenai penyakitnya mengharuskan para perawat untuk selalu siaga setiap saat, sehingga hal tersebut menjadi salah satu alasan kurangnya jam istirahat pada sebagian besar perawat di RSUD Karanganyar. Kompleksnya tuntutan pekerjaan dan tanggung jawab perawat menyebabkan profesi keperawatan rentan mengalami kelelahan kerja/burnout.

Maslach, Schaufeli, dan Leiter (2001) menjelaskan bahwa burnout adalah respons terhadap stresor emosional dan interpersonal pada tingkat yang parah dan berkepanjangan pada pekerjaan. Burnout didefinisikan oleh tiga dimensi, yaitu kelelahan emosional, depersonalisasi, dan menurunnya pencapaian prestasi diri. Kelelahan emosional yang dialami oleh perawat disebabkan oleh kompleksnya tuntutan pekerjaan perawat seperti besarnya jumlah pasien yang harus dihadapi, adanya pola kerja bergilir/shift dimana perawat 
menghabiskan sebagian besar waktu kerjanya melalui kontak langsung dengan pasien, dan adanya konflik dengan sesama perawat, dokter, pasien, dan keluarga pasien. Gejala ini ditandai dengan adanya perasaan tidak berdaya, rendahnya semangat dalam bekerja, mudah tersinggung dan marah tanpa alasan yang jelas serta merasa terjebak.

Depersonalisasi pada perawat biasanya ditunjukkan dengan adanya kecenderungan untuk menjauhkan diri serta mengurangi keterlibatan diri dalam bekerja, munculnya sikap tidak berperasaan, dan sikap acuh tak acuh terhadap berbagai aspek pekerjaan, lingkungan, dan orang sekitarnya. Hal ini ditandai dengan perawat menjadi tidak peka akan kebutuhan pasien dan mengalami kesulitan dalam memahami apa yang dirasakan oleh pasien. Apabila hal ini terjadi, maka akan mengakibatkan pelayanan kesehatan yang diberikan oleh perawat pada pasien menjadi tidak efektif. Menurunnya pencapaian prestasi diri pada perawat terjadi sebagai akibat dari adanya rasa kurang percaya diri terhadap kemampuan dan keahlian yang dimiliki oleh perawat sehingga perawat cenderung memiliki keraguan terhadap keahlian atas profesi yang dimilikinya. Jika hal ini dibiarkan terjadi, maka akan menyebabkan penurunan pada kualitas pelayanan rumah sakit.

Maslach, Schaufeli, dan Leiter (2001) membagi faktor yang memengaruhi burnout menjadi dua, yaitu faktor situasional dan faktor individual. Faktor situasional terdiri dari dua bagian yaitu karakteristik pekerjaan dan karakteristik organisasi. Sedangkan pada faktor individual meliputi tiga bagian yaitu, demografis, karakteristik kepribadian dan sikap terhadap pekerjaan.

Pada tingkat individual, tipe kepribadian memiliki peran dalam menentukan kemungkinan perawat untuk mengalami burnout. Buhler dan Land (dalam Arifianti, 2009) mengatakan bahwa kecenderungan tipe kepribadian merupakan pengaruh yang kuat dalam menentukan burnout, terutama saat mereka berada dalam lingkungan sosial, karena hal ini akan menghasilkan hasil yang negatif bagi aktivitas mereka. Selain itu, dengan adanya perbedaan kepribadian antar individu, maka akan berbeda pula cara mereka dalam menanggapi stres, sehingga apabila terjadi stres kerja yang berkepanjangan dan tidak ditangani dengan baik maka akan menyebabkan timbulnya burnout. Salah satu tipe kepribadian yang memiliki peran dalam menentukan kemungkinan perawat mengalami burnout yaitu tipe kepribadian introvert.

Eysenck (dalam Kuntadi, 2004) mengemukakan tujuh karakteristik tipe kepribadian introvert, yakni; aktivitas yang rendah/inaktivitas, ketidakmampuan bersosialisasi, menghindari risiko dan berhati-hati, kurang ekspresif, impulsif yang rendah, reflektif, dan bertanggung jawab.

Perawat dengan tipe kepribadian introvert cenderung menarik dan menutup dirinya, hal ini terlihat pada saat mereka berada dalam keadaan emosional dan sedang menghadapi masalah, sehingga apabila mereka menghadapi suatu permasalahan, perawat dengan tipe kepribadian introvert akan cenderung menyimpan permasalahannya sendiri tanpa mendapat pemecahan masalah yang tepat. Jika hal ini dibiarkan secara terus-menerus maka akan menimbulkan kelelahan emosional pada perawat. Hal ini akan berakibat pada pelayanan kesehatan yang diberikan oleh perawat dengan tipe kepribadian introvert kepada pasiennya menjadi tidak efektif. Seiring dengan timbulnya kelelahan emosional dan depersonalisasi, maka perawat dengan tipe kepribadian introvert akan mengalami penurunan pencapaian diri sebagai akibat dari beban kerja yang berat dan stres kerja pada tingkat yang parah dan berkepanjangan, sehingga akan menyebabkan burnout pada perawat dengan tipe kepribadian introvert (Purnamawati, 2015).

Berdasarkan uraian dari fenomena yang penulis temui, burnout di kalangan perawat merupakan persoalan yang sangat penting. Hal ini dikarenakan burnout dianggap memiliki dampak negatif bagi kinerja perawat dengan tipe kepribadian introvert, terutama yang 
menyangkut profesionalisme perawat dalam memberikan pelayanan kepada pasien. Perawat dengan tipe kepribadian introvert cenderung sulit untuk membicarakan dan menyelesaikan permasalahan-permasalahan yang bersifat psikologis saat menghadapi permasalahan dalam pekerjaannya, Selain itu, ketika mereka berada dalam situasi perasaan yang menekan, mereka cenderung rentan mengalami burnout (Ambarita, 2017). Hal ini didukung oleh Arifianti (2009) yang mengungkapkan bahwa bahwa apabila individu semakin introvert maka tingkat burnout akan semakin tinggi.

Tujuan dari penelitian ini adalah untuk mengetahui apakah terdapat hubungan positif yang signifikan antara tipe kepribadian introvert terhadap burnout pada perawat di RSUD Karanganyar. Adapun hipotesis penelitian adalah sebagai berikut: Terdapat hubungan positif signifikan antara tipe kepribadian introvert dengan burnout pada perawat, dimana semakin kuat skor tipe kepribadian introvert yang dimiliki oleh perawat, maka semakin tinggi pula burnout yang dialami oleh perawat di RSUD Karanganyar.

\section{METODE PENELITIAN}

\section{Variabel Penelitian}

Variabel bebas dalam penelitian ini adalah tipe kepribadian introvert, sedangkan variabel terikat adalah burnout.

\section{Subjek Penelitian}

Populasi dalam penelitian ini adalah seluruh perawat di RSUD Karanganyar yang berjumlah 269 perawat. Ukuran sampel yang menjadi partisipan dalam penelitian ini kemudian disesuaikan oleh penulis sehingga subjek penelitian adalah perawat laki-laki dan perempuan sebanyak 84 orang dengan karakteristik subjek adalah perawat yang telah bekerja minimal 1 tahun di RSUD Karanganyar.

\section{Metode dan Instrumen Pengumpulan Data}

Instrumen yang digunakan dalam penelitian ini adalah Eysenck Personality Questionaire (EPQ) dan Maslach Burnout Inventory (MBI). Skala tipe kepribadian introvert menggunakan EPQ yang dimodifikasi oleh penulis dari Heru Kuntadi (2004). Dalam skala ini tipe kepribadian introvert diukur melalui 7 karakteristik, yaitu: (a) Aktivitas yang rendah atau naktivitas, (b) Ketidakmampuan bersosialisasi, (c) Menghindari risiko dan berhati-hati, (d) Kurang ekspresif, (f) Reflektif, dan (g) Bertanggung jawab. Bentuk respon jawaban yang digunakan adalah modifikasi skala likert dengan 4 pilihan jawaban yang berbeda, mulai dari Sangat Sesuai (4), Sesuai (3), Tidak Sesuai (2) dan Sangat Tidak Sesuai (1).

Skala burnout menggunakan MBI yang disusun oleh Maslach dan Jackson (1981) dan telah diadaptasi oleh penulis. Skala ini mengukur 3 dimensi burnout, yaitu kelelahan emosi, depersonalisasi dan penurunan pencapaian prestasi diri. Bentuk respon jawaban yang digunakan adalah model skala likert dengan 4 pilihan jawaban yang berbeda, mulai dari Tidak Pernah (1), Jarang (2), Sering (3), dan Selalu (4).

Koefisien reliabilitas Alpha ditunjukkan sebesar 0,914 untuk skala burnout. Sedangkan koefisien reliabilitas Alpha ditunjukkan sebesar 0,870 untuk skala tipe kepribadian introvert.

\section{Metode Analisis Data}

Teknik analisis data yang digunakan dalam penelitian ini adalah dengan analisis korelasi Product Moment dari Spearman's Rho. 


\section{HASIL DAN PEMBAHASAN}

Berdasarkan deskripsi data penelitian seperti yang dapat dilihat pada tabel 1, sebagian besar subjek penelitian adalah subjek berjenis kelamin perempuan sebanyak 58 orang. Kemudian, usia subjek penelitian paling banyak berada pada usia 20 tahun sampai dengan 40 tahun yang mencakup 65 orang dari total subjek penelitian. Hal ini berarti bahwa usia subjek penelitian termasuk ke dalam usia perawat yang produktif. Sedangkan masa kerja subjek penelitian didominasi oleh subjek yang memiliki masa kerja kurang dari 5 tahun dan lebih dari 10 tahun.

Tabel 1.

Deskripsi Subjek $(\mathrm{N}=84)$

\begin{tabular}{llcc}
\hline \multicolumn{1}{c}{ Variabel } & \multicolumn{1}{c}{ Kategori } & Frekuensi & Total \\
\hline Jenis Kelamin & Laki-laki & 26 & 84 \\
& Perempuan & 58 & \\
\hline Usia & $20-30$ & 30 & 84 \\
& $31-40$ & 35 & \\
& $41-50$ & 14 & \\
\hline Masa Kerja & $>50$ & 5 & 84 \\
& $<5$ & 34 & \\
& $6-10$ & 13 & \\
\hline
\end{tabular}

Uji normalitas dalam penelitian ini menggunakan teknik uji One-Sample Kolmogorov-Smirnov Z (KS-Z) yang menunjukkan bahwa variabel tipe kepribadian introvert memiliki nilai (KS-Z) sebesar 0,121 dengan signifikansi 0,004 ( $<<0,05)$. Sedangkan pada variabel burnout memiliki nilai (KS-Z) sebesar 0,140 dengan signifikansi 0,000 ( $<<0,05)$. Hal ini menunjukkan bahwa data kedua variabel tersebut terdistribusi tidak normal.

Uji linearitas antara variabel burnout dengan tipe kepribadian introvert dilakukan dengan menggunakan Test of Linearity. Hasil uji coba linearitas antara kedua variabel menunjukkan nilai $\mathrm{F}$ linearity sebesar 10,606 dengan sig. $=0,002(\mathrm{p}<0,05)$ dan $\mathrm{F}$ deviation from linearity sebesar 0,619 dan sig. $=0,902(\mathrm{p}>0,05)$. Berdasarkan hal tersebut variabel burnout dan tipe kepribadian introvert memiliki hubungan yang linear.

Berdasarkan hasil uji normalitas dan uji linearitas yang telah dilakukan, diketahui bahwa data penelitian tidak terdistribusi normal dan kedua variabel memiliki hubungan yang linear. Oleh karena itu, uji hipotesis dilakukan dengan menggunakan teknik uji non parametrik. Uji korelasi yang digunakan dalam penelitian ini adalah korelasi Spearman's Rho. Hasil uji hipotesis antara variabel tipe kepribadian introvert dan burnout dapat dilihat pada tabel 2. Hasil uji hipotesis kedua variabel menunjukkan nilai koefisien korelasi sebesar 0,350 dengan nilai signifikansi sebesar $0,001(\mathrm{p}<0,05)$. Hal ini menunjukkan bahwa terdapat hubungan yang kuat dan signifikan dengan arah hubungan positif antara variabel tipe kepribadian introvert dan burnout. Kemudian, apabila dilihat dari koefisien determinan pengaruh tipe kepribadian introvert terhadap burnout diperoleh hasil koefisien determinan sebesar $\mathrm{r}^{2}=0,127$. Hal ini menunjukkan bahwa sumbangan pengaruh tipe kepribadian introvert terhadap burnout yakni sebesar $12,7 \%$.

\section{Tabel 2.}

Hasil Uji Hipotesis Hubungan

Tipe Kepribadian Introvert dan Burnout pada Perawat RSUD Karanganyar

\begin{tabular}{cccc}
\hline \multirow{2}{*}{ Variabel } & \multicolumn{3}{c}{ Spearman's Rho } \\
\cline { 2 - 4 } & $\mathbf{r}$ & Signifikansi & Keterangan \\
\hline Tipe Kepribadian Introvert dan Burnout & 0,350 & 0,001 & Signifikan \\
\hline
\end{tabular}


Hasil analisis data menunjukkan adanya hubungan positif yang signifikan antara variabel tipe kepribadian introvert dengan burnout. Hal ini memiliki arti bahwa semakin kuat skor tipe kepribadian introvert yang dimiliki oleh perawat, maka semakin tinggi pula peluang munculnya burnout. Hal ini menunjukkan bahwa hipotesis penelitian yang mengatakan terdapat hubungan yang positif signifikan antara variabel tipe kepribadian introvert dengan burnout pada perawat RSUD Karanganyar diterima.

Hasil penelitian ini sejalan dengan riset yang dilakukan sebelumnya oleh Ambarita (2017) dimana individu yang mengalami kelelahan akan merasa bahwa pekerjaannya sebagai sesuatu yang memberatkan dirinya, baik dari segi fisik, psikologis, maupun emosional. Perawat dengan tipe kepribadian introvert yang mengalami burnout cenderung mengembangkan emosi-emosi negatif, yakni perasaan frustasi, sedih, tertekan, tidak berdaya dan apatis terhadap pekerjaan. Mereka merasakan kelelahan fisik dan emosional akibat dari kompleksnya tuntutan pekerjaan sebagai seorang perawat. Kelelahan emosional yang dialami oleh perawat dengan tipe kepribadian introvert akan mengakibatkan hilangnya rasa antusias terhadap pekerjaan mereka sehingga mereka akan berperilaku menjaga jarak dan meminimalisir keterlibatan dirinya dalam pekerjaan. Selanjutnya interaksi antara kelelahan emosional dan depersonalisasi mengakibatkan tidak efektifnya perawat dengan tipe kepribadian introvert dalam melakukan pekerjaan.

Eysenck (dalam Feist \& Feist, 2009) mengatakan bahwa introvert dikarakteristikkan oleh sifat-sifat yang berlawanan dengan sifat ekstrovert. Mereka dapat digambarkan sebagai seorang yang pendiam, pasif, tidak ramah, hati-hati, suka menyendiri dan menjaga jarak dari orang lain. Eysenck mendeskripsikan bahwa seseorang dengan tipe kepribadian introvert dicirikan sebagai individu yang cenderung murung, pesimis, dan cemas apabila mereka sedang mengalami ketidakstabilan emosi. Hal tersebut menunjukkan bahwa individu dengan tipe kepribadian introvert cenderung untuk mengalami keadaan emosional yang negatif (Carver \& Scheier dalam Kuntadi, 2004).

Mereka memiliki kecenderungan yang lebih besar untuk mengalami emosi negatif yang dapat memicu terjadinya tingkat kelelahan emosional yang lebih tinggi. Mereka cenderung mengalami perasaan ketidakberdayaan yang lebih besar dan tingkat ambisi yang lebih rendah terkait pekerjaan dan prestasi pribadi (Swider \& Zimmerman, 2010). Selain itu, individu yang memiliki tipe kepribadian introvert pada umumnya adalah seorang yang pendiam dan sering menarik diri dari lingkungan sosialnya (Hall \& Lindzey dalam Tommy dkk., 2005). Hal ini memungkinkan munculnya depersonalisasi yang lebih tinggi pula. Kelelahan emosional, depersonalisasi dan rendahnya prestasi diri dapat menimbulkan burnout yang lebih tinggi pada individu dengan tipe kepribadian introvert.

Menurut Cherniss (dalam Arifianti, 2009) salah satu faktor kepribadian yang dapat menimbulkan burnout adalah tipe kepribadian introvert. Individu dengan tipe kepribadian introvert cenderung tertutup dan memendam segala permasalahan yang ada baik itu dengan rekan kerja, atasan, bawahan, keluarga dan lingkungan kerja. Perawat dengan kecenderungan introvert tidak berani untuk mengungkapkan semua beban mereka dan cenderung untuk menarik diri dari lingkungan sosialnya, sehingga kecenderungan mereka untuk mengalami burnout lebih tinggi.

Dilihat dari sisi sumbangan pengaruh tipe kepribadian introvert terhadap burnout yakni sebesar $12,7 \%$, maka masih terdapat $87,3 \%$ burnout dapat disebabkan oleh faktor lain selain tipe kepribadian introvert, baik dari faktor situasional seperti konflik peran maupun faktor individual (misalnya usia, status, dan kepribadian, yaitu self-esteem, hardiness, dan lokus kontrol eksternal). Oleh karena itu, bagi penulis selanjutnya yang ingin meneliti mengenai burnout hendaknya mempertimbangkan faktor-faktor situasional dan individual serta faktor internal maupun faktor eksternal di luar tipe kepribadian, khususnya tipe kepribadian introvert. 


\section{KESIMPULAN}

Berdasarkan hasil penelitian maka dapat ditarik kesimpulan bahwa tipe kepribadian introvert berpengaruh secara positif signifikan terhadap burnout pada perawat di RSUD Karanganyar. Dari hasil penelitian menunjukkan bahwa sebagian besar perawat di RSUD Karanganyar memiliki tipe kepribadian introvert yang berada pada kategori kuat dan sebagian besar perawat di RSUD Karanganyar merasakan burnout yang berada pada kategori sangat tinggi. Artinya, kecenderungan tipe kepribadian introvert memiliki pengaruh terhadap burnout.

\section{Saran}

Bagi institusi RSUD Karanganyar diharapkan mampu memberikan solusi terhadap burnout yang dialami oleh perawat dengan tipe kepribadian introvert. Hal tersebut dapat dilakukan dengan memberikan peluang bagi setiap perawat dengan tipe kepribadian introvert untuk melakukan diskusi, sharing, memperbanyak seminar tentang manajemen stres dan training untuk mengembangkan kemampuan perawat dengan tipe kepribadian introvert dalam memperhatikan dan mendengarkan pasien. Selain itu, pihak rumah sakit diharapkan mampu memprioritaskan kondisi dan kesejahteraan psikologis perawat sehingga burnout dalam profesi keperawatan dapat dicegah dan dihindari. Bagi peneliti selanjutnya yang ingin meneliti mengenai burnout hendaknya mempertimbangkan faktor-faktor situasional dan individual serta faktor internal maupun faktor eksternal di luar tipe kepribadian introvert.

\section{DAFTAR PUSTAKA}

Ambarita, T. (2013). Perbedaan burnout antara kepribadian introvert dan tipe kepribadian ekstrovert pada perawat di ruangan critical care. Jurnal Generasi Kampus, 6, 100 114.

Anjaswarni, Tri, \& Budi. (2002). Analisis tingkat kepuasan klien terhadap perilaku caring perawat di Rumah Sakit Umum Daerah Dr Syaiful Anwar Malang. Jurnal Keperawatan Indonesia, 6, 41 - 49. https://doi.org/10.7454/jki.v6i2.122.

Arifianti, R. P. (2009). Hubungan antara kecenderungan kepribadian ekstrovert introvert dengan burnout pada perawat. Artikel Ilmiah. Fakultas Psikologi Universitas Gunadarma.

Feist, J \& Feist, G. (2008). Theories of personality ( $7^{\text {th }}$ ed). USA: McGraw-Hill.

Juniar, H. H., Astuti, R. D., \& Iftadi, I. (2017). Analisis sistem kerja shift terhadap tingkat kelelahan dan pengukuran beban kerja fisik perawat RSUD Karanganyar. Performa, $16,44-53$.

Kementerian Kesehatan RI. (2017). Infodatin pusat data dan informasi kementerian kesehatan RI situasi tenaga keperawatan. Diakses dari : https://pusdatin.kemkes.go.id/folder/view/01/structure-publikasi-pusdatin-infodatin.html pada tanggal 7 Juni 2019.

Kuntadi, H. (2004). Gaya pengambilan keputusan ditinjau dari tipe kepribadian. (Tesis, Tidak Dipublikasikan). Yogyakarta: Program Pasca Sarjana Universitas Gajah Mada. 
Mariyanti, S., \& Citrawati, A. (2011). Burnout pada perawat yang bertugas di ruang rawat inap dan rawat jalan RSAB Harapan Kita. Jurnal Psikologi, 9, 48-59.

Maslach, C. \& Jackson, S.E. (1981). The measurement of experienced burnout. Journal of Occupational Behaviour, 2, 99-113.

P. Tommy Y. S. Suyasa, Fransisca I. R., Dewi \& Savitri, S. (2005). Perbedaan minat dalam penggunaan fungsi internet berdasarkan tipe kepribadian. Jurnal Psikologi, 3, 89-108.

Purnamawati, W. D. (2015). Perbedaan burnout pada karyawan ditinjau dari tipe kepribadian ekstrovert introvert. (Skripsi, Tidak Dipublikasikan). Pekanbaru: Fakultas Psikologi UIN Kasim Riau.

Sahrah, A. (2017). Burnout perawat perempuan ditinjau dari iklim organisasi. Psychoidea, 2, 88-97. Doi : 10.30595/psychoidea.v15i2.2448

Sholikhah, M. S., Iftadi, I., Astuti, D.R. (2017). Analisis beban kerja mental dan tingkat burnout pada perawat menggunakan metode NASA - task load index dan Maslach burnout inventory - human service survey (Studi kasus: Bangsal bedah Kanthil 1 RSUD Kabupaten Karanganyar). Seminar Nasional. Tidak Diterbitkan. Yogyakarta: Fakultas Teknik Industri Universitas Gadjah Mada.

Swider, B. W \& Zimmerman, R. D. 2010. Born to burnout: A meta-analytic path model of personality, job burnout and work outcomes. Journal of Vocational Behavior, 76, 487-506. https://doi.org/10.1016/j.jvb.2010.01.003. 